\title{
Damage field and site effects Multidisciplinary studies of the 1964 earthquake series in Central Switzerland
}

\section{Journal Article}

\section{Author(s):}

Fritsche, Stefan; Fäh, Donat; Steiner, Brian; Giardini, Domenico

Publication date:

2009

Permanent link:

https://doi.org/10.3929/ethz-b-000021269

\section{Rights / license:}

In Copyright - Non-Commercial Use Permitted

\section{Originally published in:}

Natural Hazards 48(2), https://doi.org/10.1007/s11069-008-9258-y 


\title{
Damage field and site effects: multidisciplinary studies of the 1964 earthquake series in Central Switzerland
}

\author{
Stefan Fritsche · Donat Fäh · Brian Steiner · Domenico Giardini
}

Received: 28 August 2007/ Accepted: 24 May 2008/Published online: 1 July 2008

(C) Springer Science+Business Media B.V. 2008

\begin{abstract}
Central Switzerland shows comparatively high seismic activity by Swiss standards. Many historical earthquakes are known and several of them caused damage. The last major event dates back to 1964 and has the characteristics of an earthquake swarm. Among dozens of felt shocks were two main shocks ( $\mathrm{Mw}=5$ and 5.7) that moderately damaged a limited area with hundreds of buildings suffering loss. Our aim here was to reconstruct the damage field and to analyze whether it was influenced by site effects. Given the existence of a contemporary damage assessment and other historical sources, we could describe the damage field in detail. For about $95 \%$ of the affected buildings, we could reconstruct the location and extent of loss, using assessments from the European Macroseismic Scale (EMS 98). Spatial analysis of the resulting data showed that most losses were concentrated in the villages of Sarnen and Kerns. Damage to residential houses and barns was by far most frequent (90\%), but expensive losses to the relatively few sacral buildings were responsible for almost $50 \%$ of the repair costs. We compared the damage data with deposit thickness and soil composition and carried out field experiments using $\mathrm{H} / \mathrm{V}$ spectral ratios to measure the fundamental frequency of ground resonance at 75 sites to estimate the frequency band in which amplification occurs. Our results show that locations on both thick fluviatile sediments and large alluvial cones showed higher intensities than did other ground types. Moreover, at some sites, intensity was probably increased by a layer of weathered rock below thin deposits.
\end{abstract}

Keywords Earthquakes - Historical earthquakes - Seismology · History · Damage fields · Damage assessment $\cdot$ EMS $\cdot$ Site effects $\cdot$ Switzerland

S. Fritsche $(\bowtie) \cdot$ D. Fäh · B. Steiner · D. Giardini Swiss Seismological Service, Institute of Geophysics, HPP L4, ETH Hönggerberg, 8093 Zurich, Switzerland e-mail: stefan.fritsche@sed.ethz.ch URL: http://www.seismo.ethz.ch 


\section{Introduction}

\subsection{Overview}

People living in the Sarnen region (Fig. 1) during the mid-sixties cannot forget a longlasting earthquake series that started with a main shock on February 17, 1964. This first shock reached a moment magnitude of 5 and an epicentral intensity of VII (Swiss Seismological Service 2002; Fäh et al. 2003). Several dozens of earthquakes with Mw up to 4.3 followed within the next weeks. A second main shock occurred on March 14. This event had a moment magnitude of 5.7 and reached an epicentral intensity of VII. In the subsequent 36 months, earthquake activity remained high and then fell off over the following years and has remained low until today.

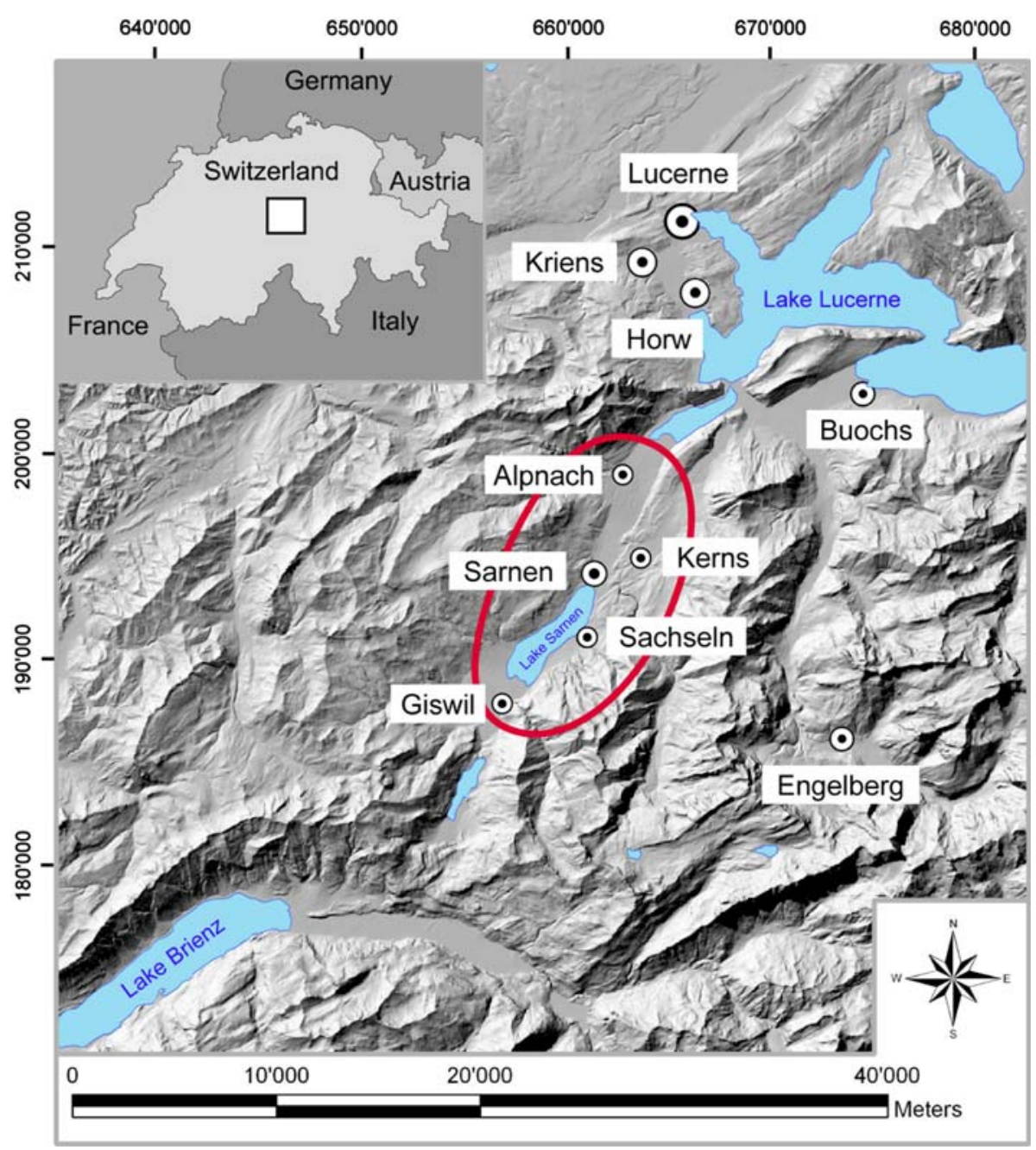

Fig. 1 Region of interest: Central Switzerland and approximate position of the damage field 
The two main shocks of February and March 1964 caused damage in a limited area (Fig. 1). However, the impact of the February event was clearly weaker, with consequences on the lower bound of intensity VII. Damage caused by the March shock exhibits full intensity VII. Although it would be wrong to describe these events as catastrophic since nobody was seriously injured, their social impact is relevant. Apart from the repair costs, the long duration of the series became burdensome for the population and administration. Particularly, in the weeks following March 14, fear and uncertainty were omnipresent and fanned by the continuous shocks as well as memories of the Skopje catastrophe of 1963 (Die Woche 1964; Tribune de Lausanne 1964). Many hundreds of citizens fled to relatives living outside the affected region (NZZ 1964). Among them were several hundred guest workers from Italy who returned home for some weeks or months (Vaterland, March 16, 1964a). A nunnery was closed temporarily and a high school was transferred to another place for a few weeks (ibid.). At the same time, the administration prepared for a potential disaster. Evacuation schedules were set up, civil protection went on alert, and military forces were held in readiness (Von Ah 1964).

Beyond such social concerns, the 1964 earthquake swarm is an important object of research. The region shows remarkable, documented historical seismicity and a contemporary damage assessment is also available. Although not complete, it provides a good basis for quantitative investigation (Kanton Obwalden 1964a, b). Furthermore, large parts of the investigated region show ground conditions that make site effects likely. Flat planes of fluviatile or lacustrine sediments are common and often combined with a high groundwater level. In addition, these areas are experiencing lively housing and industrial development. Thus, seismic risk for the region is increasing.

In this paper, we discuss the earthquake series of 1964 in terms of damage fields and site effects. Ground conditions strongly influence the intensity and duration of local ground motion and consequently affect the characteristics and distribution of damage. Since the area shows a wide variety of ground conditions, we will show that such effects are visible in the damage field of the two intensity VII events.

\subsection{Methodology}

We combined historical investigation with seismo-geological research, starting with the reconstruction of the damage field. Analyzing a large variety of historical documents enabled, with high resolution, our quantitative and qualitative description of loss in the Sarnen region. The damage assessment itself was done following the guidelines of EMS 98 (Grünthal 1998). This first step was followed by an investigation of ground conditions. For this purpose, we studied the region's geology and carried out field experiments to measure the fundamental frequency of resonance at many sites. In the third step, we spatially analyzed the assessed damage in combination with geological and geophysical findings. The resulting maps of these analyses underlie the presentation and discussion of our findings.

\subsection{Characteristics of the earthquake series and the historical seismicity of the region}

The mentioned magnitudes originate from a calibration of macroseismic data (Fäh et al. 2003). Another assessment of Mw was done by Bernardi et al. (2005) based on amplitude measurements of regional surface waves of seismograms recorded by analog instruments. For the event in February, they assign $\mathrm{Mw}=4.8$ (range of uncertainty 4.6-4.9) and 
$\mathrm{Mw}=5.3$ (range of uncertainty 5.0-5.4) for March. The earthquake series of 1964/65, a typical earthquake swarm, differs from common main shock/after shock sequences by an increase/decrease in individual magnitudes with no apparent pattern. ECOS (Swiss Seismological Service 2002), the Swiss Earthquake Catalogue, quotes a series of about 70 verified, felt events for that period (Table 1).

Several contemporary newspaper articles point out that "many hundred" earthquakes were felt in the epicentral region during the series (Stuttgarter-Zeitung 1964). In fact, the given list should be much longer. It is practically impossible to reconstruct such a long and intensive series from macroseismic data only. However, we may assume that the events missing in Table 1 were of minor intensity. Many reports describe earthquakes accompanied by a noise like an explosion or the rumbling of a thunderbolt (Vaterland, February 18, 1964b; NZZ 1964).

Looking further back in time, we see periods with high seismic activity as a general characteristic of this region (Swiss Seismological Service 2002). Figure 2 reviews the known historic seismicity of the region with $\mathrm{Io} \geq 5$. Since it is a problem to locate epicenters accurately with only macroseismic data, Fig. 2 includes the range of uncertainty. The series in Altdorf (1774, 10 known events) as well as two earlier series near Sarnen (1777, 11 known events but a contemporary observer speaks of 60 felt shocks, and 19 events in 1917) show a pattern similar to that of 1964 (Fig. 2 and Gisler et al. 2004). The strongest known event for the region dates back to 1601 with Imax $=$ VIII and Mw 6.2 (Schwarz-Zanetti et al. 2003, 2006). With the exception of the 1917 events

Table 1 Earthquakes of the 1964/66 swarm verified by the Swiss Seismological Service (ECOS 2002)

\begin{tabular}{|c|c|c|c|c|c|c|c|c|}
\hline Date & $\mathrm{Mw}$ & Io & Date & Mw & Io & Date & Mw & Io \\
\hline 17.02 .64 & 5 & 7 & 28.02 .64 & 1.9 & $2-3$ & 18.03 .64 & 2.7 & $3-4$ \\
\hline 17.02 .64 & 2.3 & 3 & 04.03 .64 & 2.3 & 3 & 19.03 .64 & 2.3 & 3 \\
\hline 17.02 .64 & 2.3 & 3 & 06.03 .64 & 2.3 & 3 & 25.03 .64 & 2.3 & 3 \\
\hline 17.02 .64 & 2.3 & 3 & 08.03 .64 & 2.3 & 3 & 26.03 .64 & 2.7 & $3-4$ \\
\hline 17.02 .64 & 3.1 & 4 & 08.03 .64 & 2.3 & 3 & 12.04 .64 & 2.3 & 3 \\
\hline 17.02 .64 & 1.9 & $2-3$ & 08.03 .64 & 2.3 & 3 & 17.04 .64 & 2.3 & 3 \\
\hline 17.02 .64 & 1.9 & $2-3$ & 11.03 .64 & 4.3 & $5-6$ & 14.05 .64 & 1.9 & $2-3$ \\
\hline 17.02 .64 & 1.9 & $2-3$ & 13.03 .64 & 3.1 & 4 & 20.05 .64 & 2.5 & 3 \\
\hline 17.02 .64 & 1.9 & $2-3$ & 14.03 .64 & 2.3 & 3 & 18.06 .64 & 3.1 & 4 \\
\hline 18.02 .64 & 1.9 & $2-3$ & 14.03 .64 & 5.7 & 7 & 08.09 .64 & 2.7 & $3-4$ \\
\hline 18.02 .64 & 3.1 & 4 & 14.03 .64 & 2.3 & 3 & 24.10 .64 & 2.6 & - \\
\hline 18.02 .64 & 2.3 & 3 & 14.03 .64 & 3.9 & 5 & 11.11 .64 & 3.5 & 4.5 \\
\hline 18.02 .64 & 1.5 & 2 & 14.03 .64 & 2.7 & $3-4$ & 28.11 .64 & 2.7 & $3-4$ \\
\hline 18.02 .64 & 2.7 & $3-4$ & 14.03 .64 & 2.3 & 3 & 20.08 .65 & 3.1 & 4 \\
\hline 18.02 .64 & 2.7 & $3-4$ & 15.03 .64 & 2.7 & $3-4$ & 27.08 .65 & 3.1 & 4 \\
\hline 18.02 .64 & 2.3 & 3 & 15.03 .64 & 3.4 & 4 & 11.10 .65 & 3.1 & 4 \\
\hline 18.02 .64 & 3.1 & 4 & 15.03 .64 & 2.3 & 3 & 08.11 .65 & 3.1 & 4 \\
\hline 21.02 .64 & 3.1 & 4 & 16.03 .64 & 3.1 & 4 & 14.12 .65 & 2.7 & $3-4$ \\
\hline 22.02 .64 & 2.3 & 3 & 16.03 .64 & 2.7 & $3-4$ & 17.12 .65 & 2.7 & $3-4$ \\
\hline 23.02 .64 & 2.3 & 3 & 16.03 .64 & 2.1 & - & 04.03 .66 & 3.1 & 4 \\
\hline 25.02 .64 & 3.1 & 4 & 17.03 .64 & 2.7 & $3-4$ & 13.04 .66 & 2.7 & $3-4$ \\
\hline 27.02 .64 & 2.3 & 3 & 17.03 .64 & 2.3 & 3 & 22.04 .66 & 3.1 & 4 \\
\hline
\end{tabular}




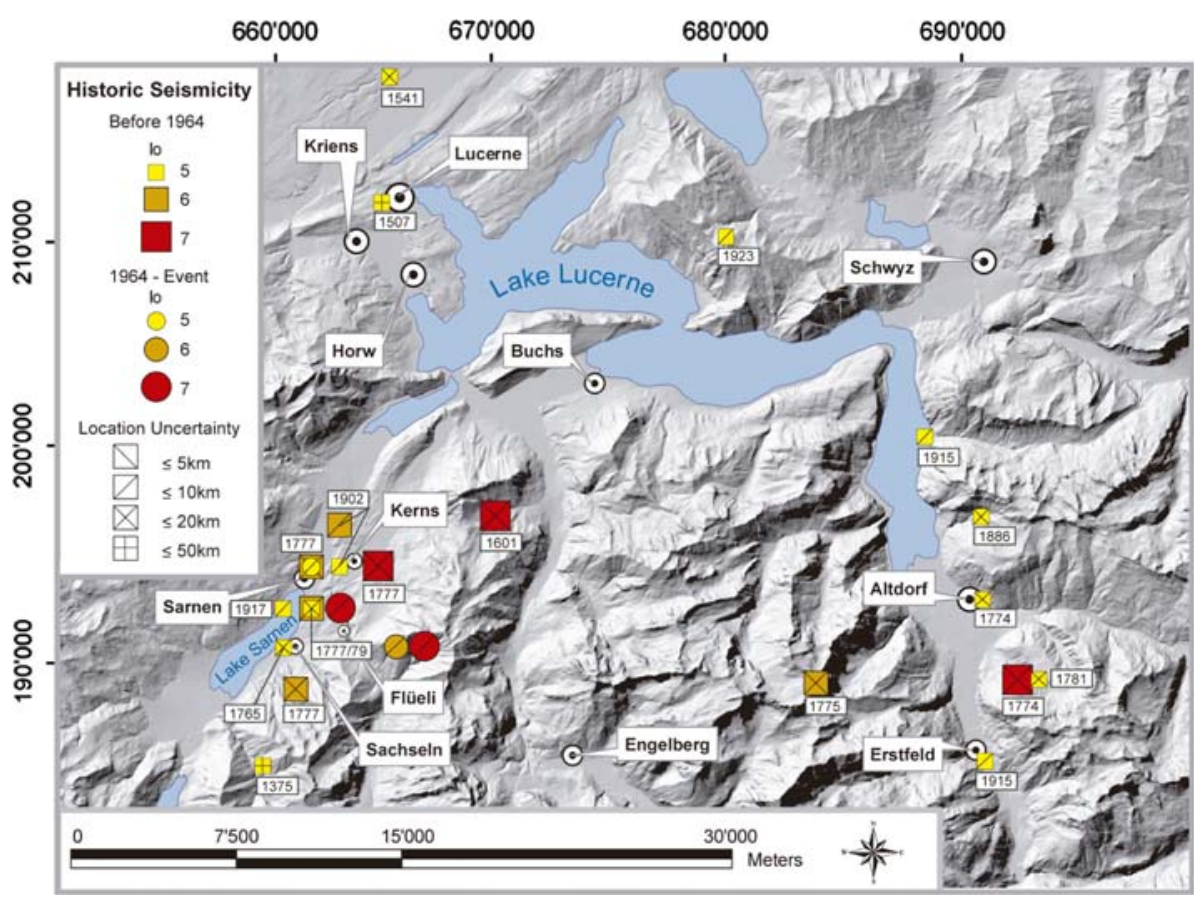

Fig. 2 Historic seismicity of Central Switzerland based on ECOS data with Io $\geq 5$

(no intensities higher than 5), all these series included shocks that caused slight (1777) to moderate (1601, 1774, and 1964) damage. Since the swarm event of 1964, seismic activity has remained low with only a few dozen events smaller than $\mathrm{Mw}=3$ and a couple in the range $\mathrm{Mw}=3-3.7$.

A characteristic of the earthquakes here is that probably all occurred close to the surface. Figures 3 and 4 show that for the two main shocks of the 1964 series, the decrease in intensity with distance is remarkably strong, particularly from intensity VII down to intensity V. In general, this kind of observation is associated with shallow epicenters. Several indications support the assumption that this pattern holds throughout the region. The few earthquakes that occurred in this area during the last 30 years were at shallow depth. For example, Deichmann et al. (2000) demonstrated that the two small 1985 events at Kerns $(\mathrm{Mw}=2.5)$ and Sachseln $(\mathrm{Mw}=2.9)$ took place in the upper tertiary sediment layer at 1-2 km depth. They argue that the recorded data allow no consistent solution for a focal mechanism that assumes a deeper epicenter. We note that after a period of extremely heavy rainfall from August 19-August 23 2005, several micro-earthquakes (Mw 1.3-1.7) were recorded for August 23-August 26 (Swiss Seismological Service 2002). The temporal linking of these events (heavy rainfall and micro-earthquake activity) makes a correlation likely. We suppose that the quick release of energy results from the increased pore water pressure close to the surface (Husen et al. 2007; Hainzl 2006). These observations strongly indicate but do not prove shallow epicenters in these areas. Therefore, the seismic activity has been too sparse for the time since seismic instrumentation has enabled accurate recording and analysis. 


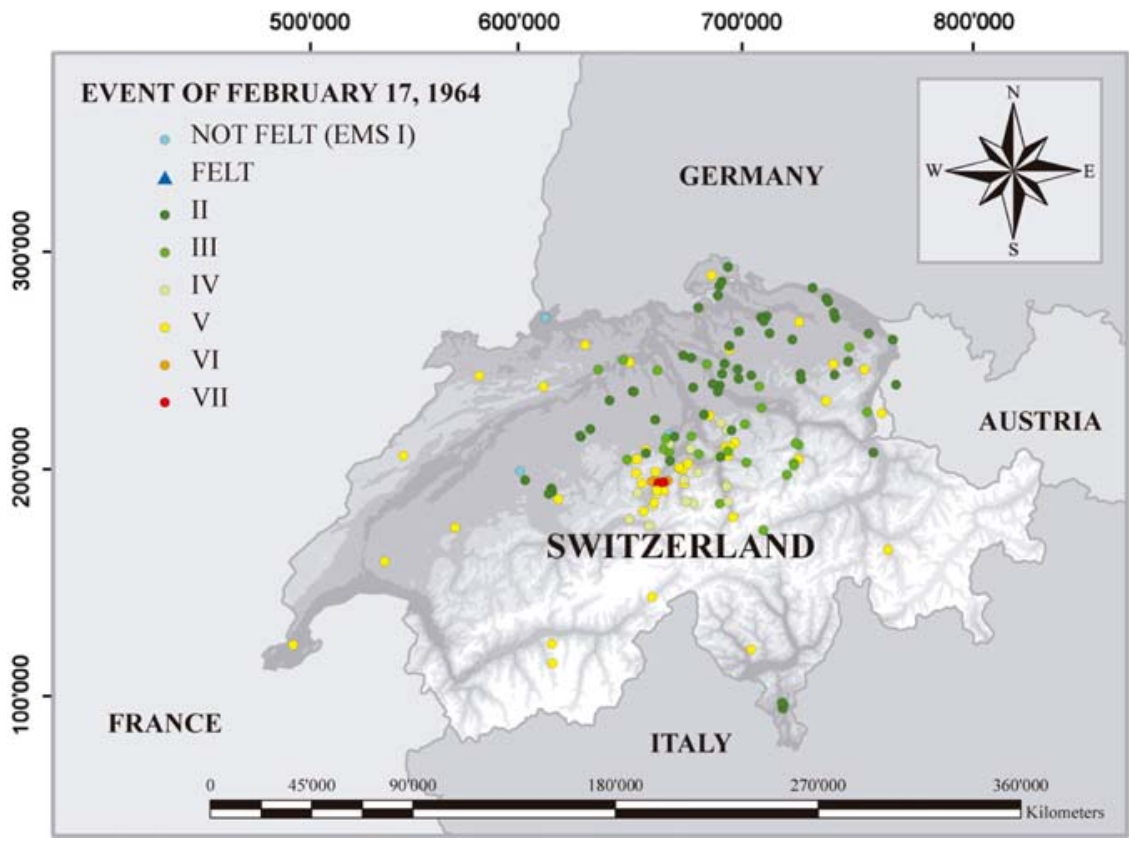

Fig. 3 Macroseismic map of the February 17, 1964 event based on ECOS data (Swiss Seismological Service 2002)

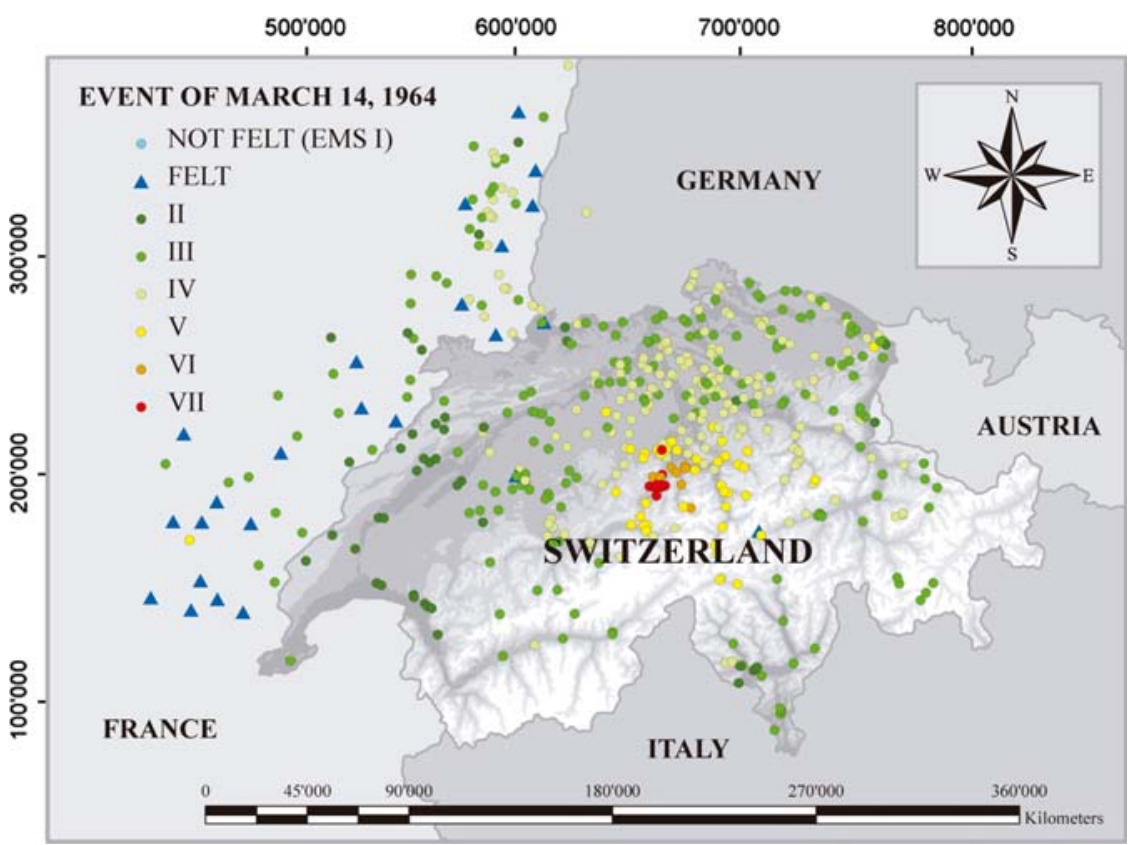

Fig. 4 Macroseismic map of the March 14, 1964 event based on ECOS data (Swiss Seismological Service 2002; BRGM, EDF and IRSN 2005) 


\section{Reconstruction of the 1964 damage field}

\subsection{Overview}

The most important set of documents, a contemporary damage assessment (Kanton Obwalden 1964b. Schadenserhebung zu den Erdbeben von 1964 in der Region Sarnen), is not preserved completely. However, we have been able to reconstruct the damage field almost entirely.

The contemporary damage assessment formed the basis of our work. It was done by officials of the cantonal administration in the months after the second main shock of March 14, 1964 and covered the stock of damaged buildings in private hands. The motivation for this assessment was that Swiss Building Insurance companies were disposed to cover part of the repairs. Individual losses were assessed on so-called "field-protocols" by a short damage description and an amount in Swiss currency. Later, these protocols were compiled in lists that mention only an owner, the sum of money, the type of building, and a location. While these lists are preserved completely, almost half the original "field protocols" are lost. In addition, the loss to public buildings including churches and chapels is only partly covered by this official assessment. Thus, we explored more administrative documents, newspaper articles, and journals. Of particular interest is an administrative list of all damaged chapels and churches (Kanton Obwalden 1964a. List of damaged churches). Although this document describes the loss in monetary terms only, it is the most important source on ecclesiastical buildings. We found more information about many of these ecclesiastical buildings in diverse newspaper articles, and in several cases even a photograph of the damage.

Our attempt to attribute damage to the first or second main shock failed due to a lack of systematic information. While the field protocols partly associate the damage with one of the two main shocks, the recapitulating lists don't separate them. Nevertheless, given this information from newspaper/journal articles, we concluded that the impact of the March 14 shock was considerably stronger. Our finding is confirmed by the macroseismic fields of the two events based on independent data (Figs. 3, 4).

A time-consuming task was locating the several hundred damaged buildings mentioned in the field protocols. House numbers were not in use in 1964 and even street names were frequently omitted. Property names were often the only information concerning the location of the buildings. Such property names or "Flurnamen" in German reduce the type of property to a couple of words and have been used for hundreds of years. Despite these obstacles, we assigned locations for about $95 \%$ of the damaged buildings, most exactly, and the rest with an error of within $100 \mathrm{~m}$. The remaining $5 \%$ could not be located or were not accurate enough to be used in our analyses.

We also investigated the quantity and quality of the building stock for the mid-sixties. This kind of information is essential for a quantitative damage rating and is integral to the procedures given by EMS 98 (Grünthal 1998). Thus, we examined pictures showing the region in the mid-sixties, studied traditionally built houses, interviewed engineers and architects, and incorporated statistical data as well as maps showing the villages. Since our data contain excellent information on repair costs, we finally extrapolated the 1964 prices of the building construction sector to a contemporary level. This proved interesting with respect to a monetary assessment, but also useful for classifying damage grades, since it allowed comparison with present prices. 


\subsection{Damage assessment}

The damage assessment was done with procedures of the European Macroseismic Scale 98 (EMS 98) published by Grünthal (1998). The underlying principle is simple and rests upon two input parameters: vulnerability class (VC) and damage grade (DG). While the vulnerability class describes how well a given building resists ground motion, the damage grade quantifies the real damage. Classification of vulnerability is based on 15 different types of buildings subdivided into four general structure classes: masonry, reinforced concrete, steel, and wood structures. Each building type is related to one vulnerability class ranging from class A (very vulnerable, equivalent to rubble stone or adobe structures) to class $\mathrm{F}$ (having a high level of earthquake-resistant design). Other attributes such as quality and workmanship, state of preservation, and regularity of the ground plan may affect the appropriate class or explain an upgrading or downgrading of the object if information is available. The damage to buildings, on the other hand, is grouped into five classes depending on the grade of failure in structural and non-structural elements. The scale ranges from DG 1 (negligible to slight damage: no structural damage, slight no structural damage) to DG 5 (destruction: very heavy structural damage). Finally, EMS 98 contains a simple statistical tool that allows us to quantify the grade of loss in a given damage field (ibid., 25-26). It is based on the terms "few," "many," and "most" to represent a narrowly overlapping percentage scale $(0-20 \%, 10-60 \%$, and $50-100 \%)$. It helps to quantify the mixed damage to buildings of different vulnerability classes with short and clear statements. These summaries allow us to assign one of the 12 intensity degrees provided by EMS 98: from intensity I (earthquake not felt) to intensity XII (devastating).

Since the 1964 earthquake swarm occurred more than 40 years ago and most information on it is in marginal written form, we had to make certain assumptions, particularly about building vulnerability. We specify and explain them below.

\subsection{Results of the damage assessment}

Table 2 summarizes the damage to buildings in money and damage grades for the affected villages of Sarnen, Kerns, Alpnach, Sachseln, Giswil, and Engelberg. We assume that the listing includes all cases of loss for damage grades 2 and higher (with a small exception, see Figs. 6, 7). Numerous cases of damage grade 1 were probably overlooked during the 1964 assessment since they fell below the criteria for receiving compensation.

While the loss expenses rely on the assessment documents described above, the listed damage grades reflect the results of the procedure presented previously. The calculation of the price rise was done using the general consumer price index provided by the Swiss Federal Statistical Office (2006). Continuous index series for prices describing price growth in building industries are not available. Extrapolating an existing series from 19401991 (Ritzmann-Blickenstorfer 1996) and from 1998-2005 (Swiss Federal Statistical Office 2006) shows a slightly smaller increase compared to the general consumer price index. Using this index, the damage would reach today about CHF 14 million.

For about 450 of the 842 affected buildings, our assessment rests upon primary data sources offering precise information about the kind of damage. Most data come from the field protocols. A few dozen other case descriptions were found in newspapers and magazines including some photographs. These short and rudimentary descriptions usually enabled identification of the building type. We distinguished between residential houses, barns, sheds, shanties and industrial or sacral buildings. A combination of building type, 


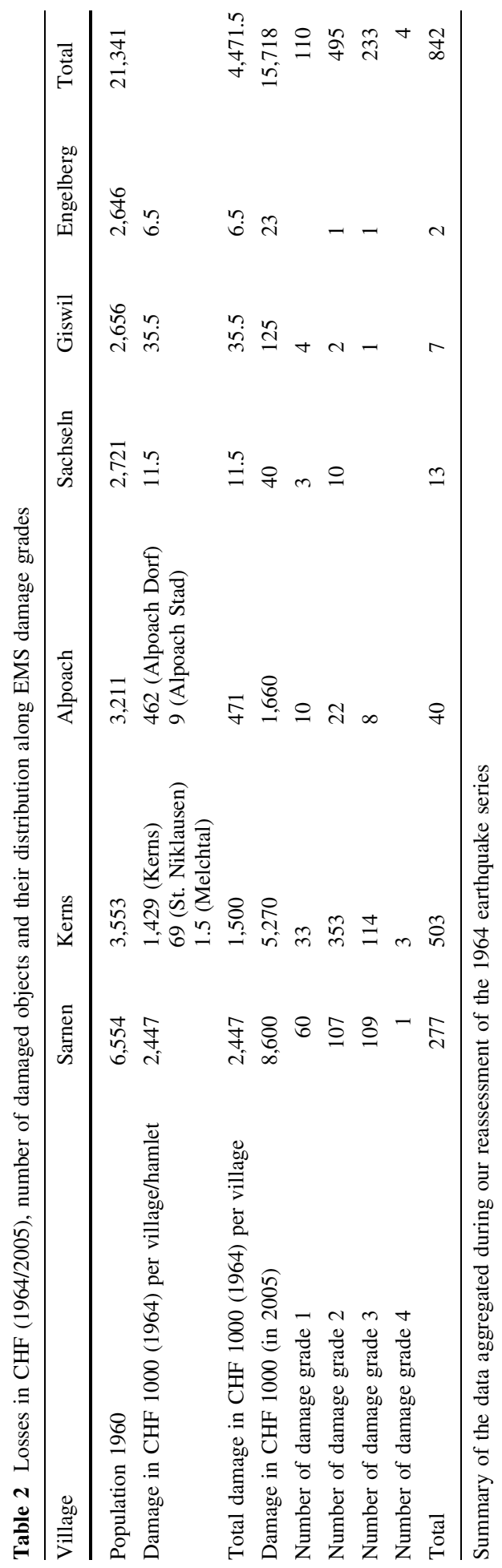


damage description, and repair costs finally formed the framework for our damage roster following EMS 98 (Table 3).

The remaining losses (about 400 cases) had to be rated almost exclusively on monetary information. For about $20 \%$ of them, building type and/or some other marginal information was at hand. From statistical analyses of those cases including a verbal description, we set up a scale that separates damage grades from 1 to 3 .

$$
\text { CHF } 0<\text { DG } 1<\text { CHF } 400<\text { DG } 2<\text { CHF } 3500<\text { DG } 3
$$

Damage of grade 4 was not assigned within this part of the data, because there were a few cases of this damage grade to achieve statistically significant values (Table 4). However, it is not likely that a significant number of damage grade 4 has been passed over.

Our data gathering illuminated the composition of damaged building stock and the cost distribution per building type. While Fig. 6a divides the damaged stock into groups of comparable building types including the not definable, Fig. $6 \mathrm{~b}$ illustrates the loss distribution in CHF per building type. Both Fig. 6a, b rely on assessed data.

Further investigations have shown that the categories "sacral-, industrial, and public buildings" are completely identified in our data. Thus, we substitute, in Fig. 7a, the "not defined" building class by larger values for the "residential building class" and the "barn class" proportional to the values as they are given in Fig. 6a (two third of residential buildings, one third barns). Figure 7 a thus shows the composition of damaged building

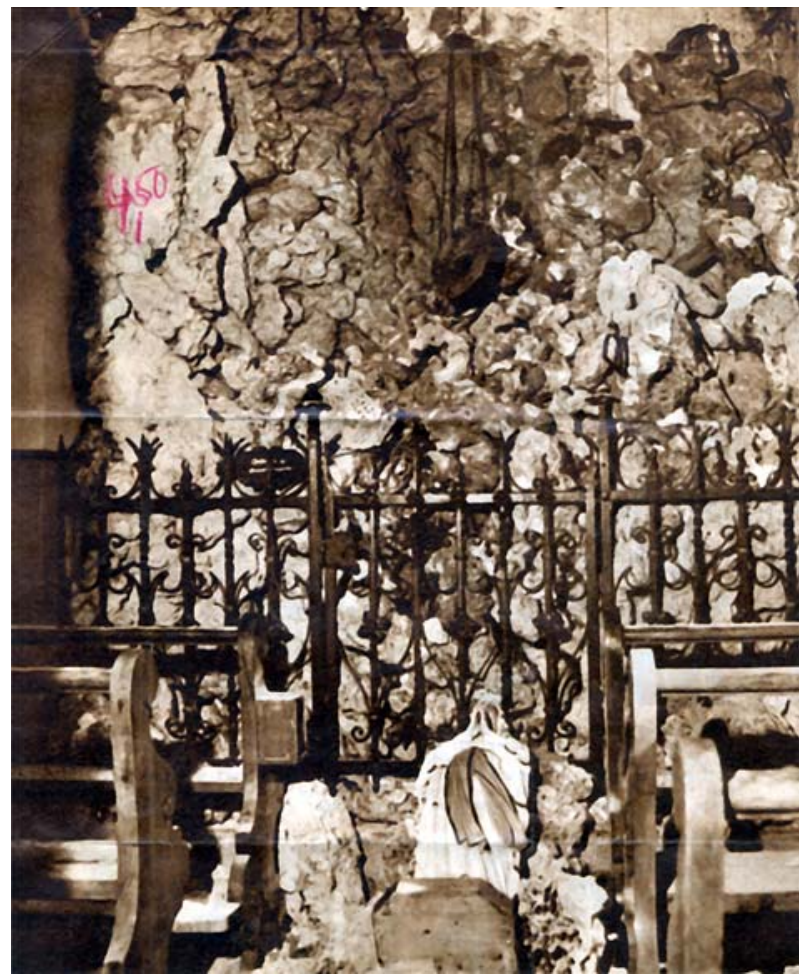

Fig. 5 The "Antonius Chapel" in Sarnen was built in 1646. The Earthquakes of 1964 destroyed a precious relief. (Allgemeine Volkszeitung 1964) 


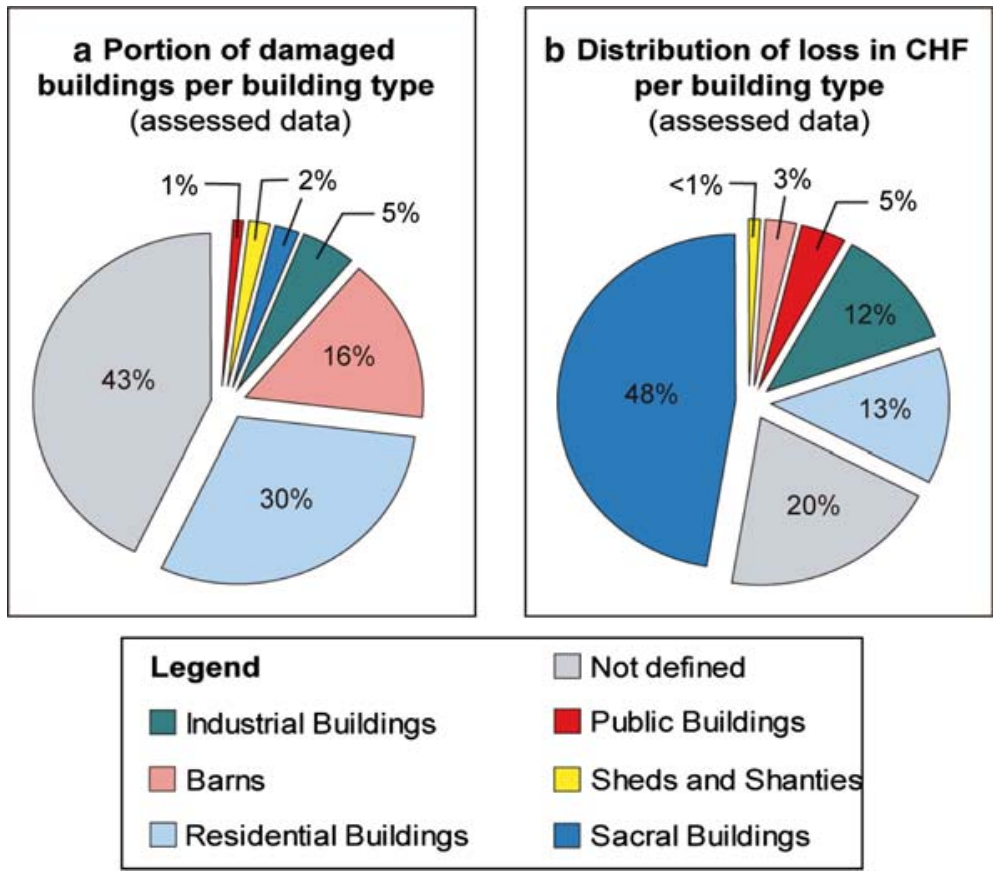

Fig. 6 Portion of damaged buildings per building type (a) and distribution of loss per building type in CHF (b) based on assessed data including the official contemporary damage assessment as well as the mentioned list describing the losses on ecclesial buildings

stock in 1964 without the gap of undefined buildings. Figure 7b shows the corresponding extrapolation for the distribution of loss in CHF per building type. In contrast to the former extrapolation (7a), the result of this extrapolation shows a significant change in the "public building" class. This has to do with the fact that for some damaged buildings of this class no monetary information is available. We assume that public buildings hold a significantly higher share of the total costs of loss (approximately in a range between 6\% and 10\%).

Comparing Fig. 7a, b gives insights into the loss structure. Damage to the "public building" class, for example, covers only about $1 \%$ of the affected building stock, but explained about $10 \%$ of the total repair costs. Even more remarkably, harm to a few sacral buildings was responsible for almost $50 \%$ of the total loss. To a lesser extent, such an observation is also valid for industrial buildings. In contrast, residential buildings and barns show inverse ratios: the large number of residential buildings and barns (together representing about $90 \%$ of all damaged buildings) sustained only $32 \%$ of the total costs. These findings make sense since they are primarily related to vulnerability, size, and value of the respective buildings. Public and industrial buildings tend to be larger than residential buildings or barns and sacral buildings not only show a higher vulnerability than most other classes but also include very valuable components (Fig. 5). An individual assessment of these building characteristics was not feasible due to the large number of damaged objects. We thus concentrated on evaluating the 1964 building stock vulnerability within the categories used so far. This task was completed on the basis of photographs, field visits, and study of the region's typical construction. Table 4 summarizes these results. 


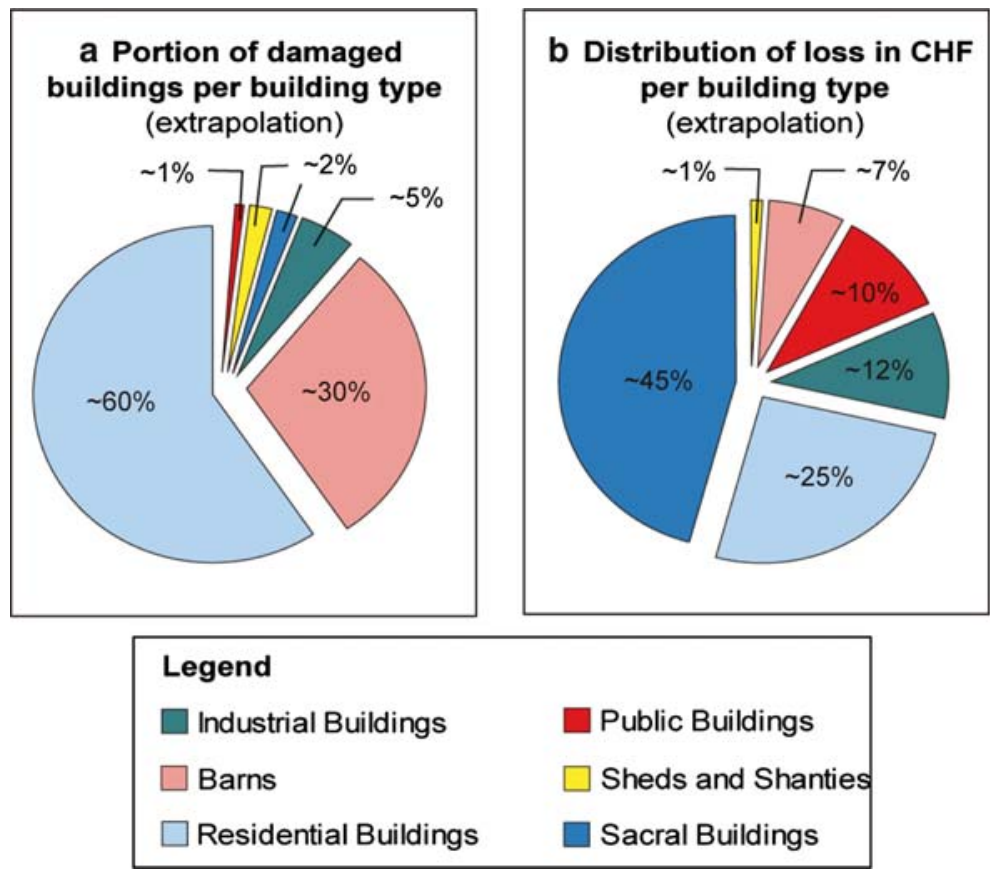

Fig. 7 Portion of damaged buildings per building type (a) and distribution of loss per building type in CHF (b); extrapolation of Fig. 6, including an adjustment of the public building class. Investigation has shown that these categories were not covered completely by the contemporary assessment

Table 3 Roster used to assign damage grades

\begin{tabular}{|c|c|c|c|}
\hline $\begin{array}{l}\text { Damage } \\
\text { grade }\end{array}$ & Typical damage & $\begin{array}{l}\text { Examples of the original damage } \\
\text { assessment (1964) }\end{array}$ & $\begin{array}{l}\text { Damage } \\
\text { in } \mathrm{CHF}\end{array}$ \\
\hline \multirow[t]{2}{*}{1} & \multirow{2}{*}{$\begin{array}{l}\text { Hair-line cracks and fissures } \\
\text { in walls. Fall of small } \\
\text { pieces of plaster or gypsum }\end{array}$} & Barn: Very slight cracks & 120 \\
\hline & & $\begin{array}{l}\text { House: Slight cracks in walls and } \\
\text { fissures in flagstones of bathroom }\end{array}$ & 430 \\
\hline \multirow[t]{2}{*}{2} & \multirow[t]{2}{*}{$\begin{array}{l}\text { Partly collapsed chimneys. } \\
\text { Slightly damaged roofs } \\
\text { Cracks in walls }\end{array}$} & $\begin{array}{l}\text { House: Damaged chimneys, } \\
\text { damaged roof, harmed gypsum, } \\
\text { slight cracks in walls }\end{array}$ & 2,400 \\
\hline & & $\begin{array}{l}\text { House: Three damaged chimneys, } \\
\text { cracks in walls }\end{array}$ & 1,230 \\
\hline \multirow[t]{2}{*}{3} & \multirow{2}{*}{$\begin{array}{l}\text { Heavily damaged chimneys. } \\
\text { Large cracks in most walls. } \\
\text { Failure of non-structural } \\
\text { elements (partitions walls) }\end{array}$} & $\begin{array}{l}\text { House: Damaged chimneys, a } \\
\text { collapsed stove, two collapsed } \\
\text { walls and cracked walls }\end{array}$ & 3,735 \\
\hline & & $\begin{array}{l}\text { House: Two collapsed chimneys at } \\
\text { the roofline and a damaged roof, } \\
\text { damaged stoves and harmed } \\
\text { gypsum }\end{array}$ & 4,060 \\
\hline \multirow[t]{2}{*}{4} & \multirow{2}{*}{$\begin{array}{l}\text { Serious failure of walls } \\
\text { and/or roofs. (Only a few } \\
\text { cases, all of them belong to } \\
\text { vulnerability class A.) }\end{array}$} & $\begin{array}{l}\text { Barn: Walls partly collapsed, danger } \\
\text { of collapse! }\end{array}$ & 2,450 \\
\hline & & $\begin{array}{l}\text { Garage: Walls heavily cracked, } \\
\text { danger of collapse! }\end{array}$ & 6,380 \\
\hline
\end{tabular}

The quoted amounts of money refer to the original data of 1964; the price rise is not included 
Table 4 Building types and vulnerability classes

\begin{tabular}{|c|c|c|}
\hline Type of building & Characteristics & $\begin{array}{l}\text { Vulnerability } \\
\text { class (EMS 98) }\end{array}$ \\
\hline $\begin{array}{l}\text { Residential } \\
\quad \text { buildings } \\
\text { (traditional) }\end{array}$ & $\begin{array}{l}\text { Two to four stories. Groundwork of masonry in simple stone, } \\
\text { massive stone, or manufactured stone units up to the first } \\
\text { floor. Upper stories: Massive timber construction. Free } \\
\text { standing, regular groundwork. Many old buildings among } \\
\text { them. Variable state of preservation. }\end{array}$ & B-C- - D \\
\hline $\begin{array}{r}\text { Residential } \\
\text { buildings } \\
\text { (modern) }\end{array}$ & $\begin{array}{l}\text { Two of four stories. Mostly masonry constructions in } \\
\text { manufactured stone units. Free standing, regular ground } \\
\text { plan. Generally in a good state of preservation. }\end{array}$ & $\underline{\text { B-C-D }}$ \\
\hline Sacral buildings & $\begin{array}{l}\text { Masonry construction in field-, simple, or massive stone. } \\
\text { Particularly the vaults show high vulnerability. Most of } \\
\text { these buildings are several hundred years old. Variable } \\
\text { state of preservation. Irregular ground plan. }\end{array}$ & A- $\underline{\mathbf{B}}$ \\
\hline Public buildings & $\begin{array}{l}\text { Up to four stories. Masonry construction in massive stone } \\
\text { or manufactured stone units. Generally in a good state } \\
\text { of preservation. }\end{array}$ & B-C- - D \\
\hline Barns & $\begin{array}{l}\text { Mostly single story buildings with regular groundwork. } \\
\text { Masonry and timber constructions. Very often partly in } \\
\text { masonry, partly in timber. Clearly weaker construction than } \\
\text { residential buildings. Masonry in fieldstone, simple stone, or } \\
\text { manufactured stone units. Variable state of preservation. }\end{array}$ & $\underline{\mathbf{A}-\mathbf{B}-\mathrm{C}}$ \\
\hline Shed and shanties & $\begin{array}{l}\text { Small single story buildings in timber, masonry, or a mixture } \\
\text { of them. Weak constructions. Often in bad conditions. }\end{array}$ & $\underline{\mathbf{A}-\mathrm{B}}$ \\
\hline $\begin{array}{l}\text { Industrial } \\
\text { buildings }\end{array}$ & $\begin{array}{l}\text { Very different types of building. Construction in manufactured } \\
\text { stone units, reinforced concrete, timber, or steel. Mixtures } \\
\text { of those materials, Partly irregular ground plan. One to four } \\
\text { stories. }\end{array}$ & B-C - -D \\
\hline
\end{tabular}

Letters with underscore indicate the most likely vulnerability class. It is not a contradiction that modern residential buildings tend to be vulnerable than traditional residential buildings since the former consist to a considerable higher degree of masonry than the latter

Accurate quantitative data concerning the distribution of building vulnerability for the mid-sixties are not available. The following values thus rely on estimations. About $20 \%$ of the mid-sixties building stock in the Sarnen region belonged to vulnerability Class A (chapels, barns, shed, and shanties). About 30\% belonged to Class B (mostly barns, churches, and residential buildings). Another $40 \%$ of the buildings are part of Class $\mathrm{C}$ (residential buildings, public, and some industrial buildings). A minority of about $10 \%$ belongs to Class D (above average, well built residential, public, and industrial buildings).

\subsection{Discussion of the intensity and damage distribution}

Figure 8 summarizes the results of the damage assessment on a background indicating the existing building stock around 1969 taken from maps published in 1971 (Eidg. Landestopographie), the best available dataset for the respective time. Each colored square represents a damaged object of a certain damage grade. The teal colored areas represent major quaternary deposits (Schindler et al. 1996). Since quantitative allocation of the loss to one of the two main events was not obtainable, Fig. 8 includes all losses. Many sources giving temporal reference, however, point out explicitly that both main shocks shaped the total damage. Naturally, the first main shock weakened building structures and made them 


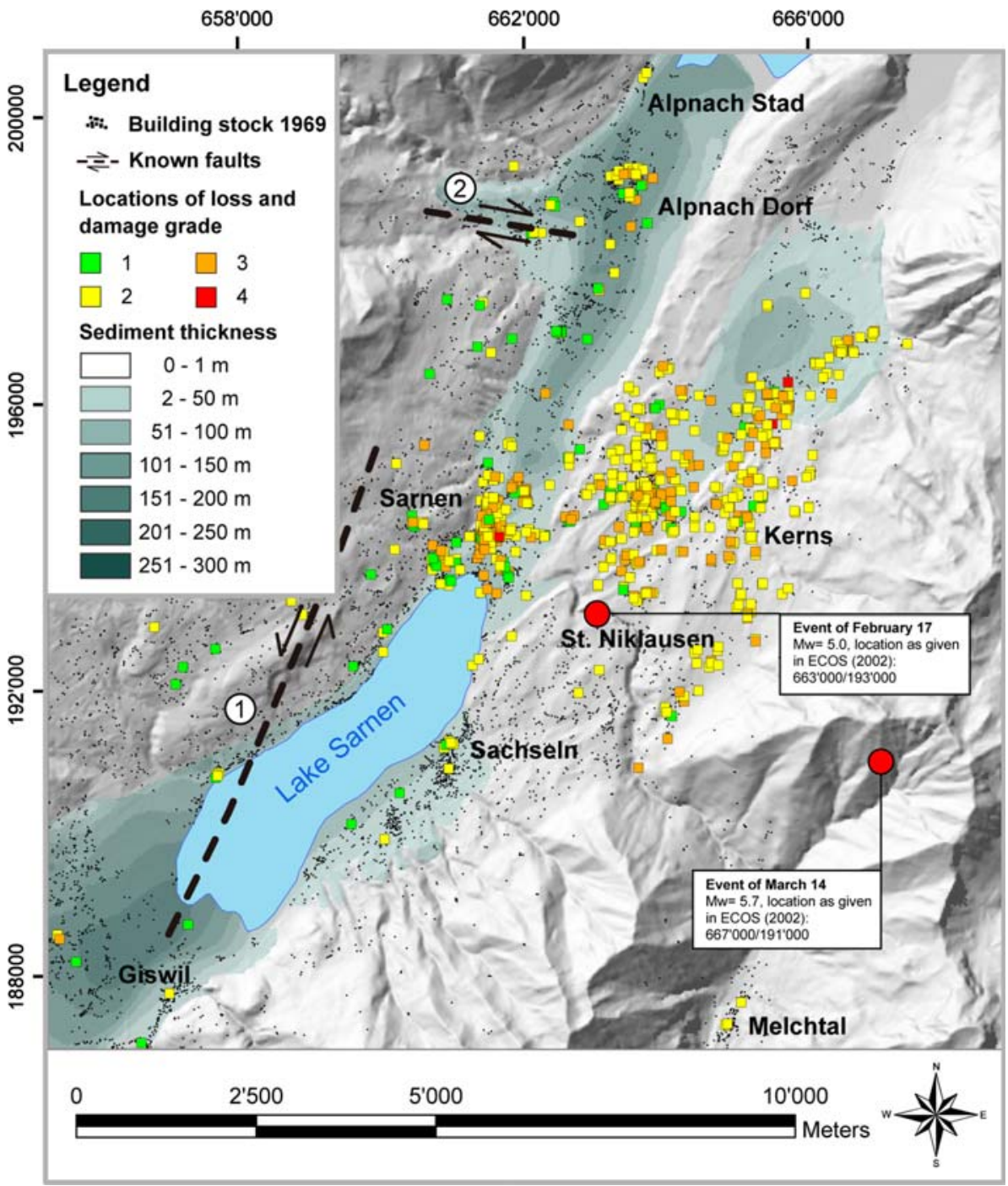

Fig. 8 Damage field of the 1964 earthquake series including damage grades, building stock (Eidg. Landestopographie 1971a, b), and areas of thick deposits (Beer 1997). The figure includes all damaged buildings mentioned in the contemporary damage assessment. The epicenters are given according to ECOS (2002). Since localization relies on macroseismic data, location uncertainty is $10 \mathrm{~km}$ in the north-south as well as east-west directions

more vulnerable to the second. Despite this lack of information, intensity VII is an appropriate qualitative value for both the two main shocks and the damage related to them. We concluded that the second event was definitely of stronger intensity. This finding is also clear from the macroseismic fields of the two main shocks (Figs. 3 and 4). Earlier intensity estimations (ECOS 2002) are also confirmed by this result. It may appear contradictory that the main shocks when individually assessed show the same intensity as both main events together. However, around intensity VII, the span from one intensity degree to the next is 
fairly large. This applies particularly for the intensities describing damage from intensity VI onward.

Due to sparse information, it wasn't possible to quantitatively analyze whether the epicenters of the two main shocks were at the same (or a nearby) location, nor do qualitative investigations give definitive help. In discussing the damage distribution below, we thus assume that both main shocks occurred at the same or a nearby location.

A general characteristic of the damage field is its limited area: a few dozen square kilometers. The largest share of damaged buildings occurs in the villages of Sarnen and Kerns. Another location showing comparably high damage is Alpnach Dorf. Further north and south, the number of damaged objects decreases dramatically and remains low. To the south, even in Sachseln and Giswil, damage occurred sparsely. Only a few additional losses (of minor extent) can be recognized outside the area shown in Fig. 8 (in Lucerne, $20 \mathrm{~km}$ north and Engelberg, $20 \mathrm{~km}$ southeast of Sarnen). A more detailed insight into the damage distribution is given by Figs. 9 and 10 within which the area is split into squares of $200 \mathrm{~m}$ on a side. Figure 9 illustrates the damage density as a function of damaged buildings and building stock (damaged buildings divided by existing buildings per area); Fig. 10 shows the average loss per damaged building and grid unit.

While Fig. 9 does not consider damage grades at all, Fig. 10 incorporates the intensity of damage in monetary terms. The results of the two calculations differ significantly. Damage density, as shown in Fig. 9, tends to be higher in Kerns. In contrast, Fig. 10 suggests that the average loss per building is larger in Sarnen. The reason for this disparity is explained by the quality and composition of the building stock. Unlike Kerns, Sarnen was already in the mid-sixties a more "town-like" village including an industrial area in the north as well as a southern zone with many large public and culturally valuable structures (schoolhouses, churches, and a monastery). Damage to these was costly, as we have seen in the last paragraph, raising the average loss significantly (Fig. 7). Second, in contrast to Sarnen, Kerns is a widespread village dominated by rural buildings of a simpler standard. Repair costs there were generally lower. Finally, many of Kern's structures are timber and thus less vulnerable to certain types of damage (Fig. 10). The higher damage density (but not cost) in the Kerns region is possibly the result of a larger portion of buildings of low standard and poor condition (particularly barns). Looking more closely at the damage in Alpnach, we see that it is less serious than it appears from Fig. 8. The damage density (Fig. 9) is clearly lower than for most parts of Sarnen and Kerns and the relatively high loss per building and grid unit (Fig. 10) is due to a few cases of expensive damage to buildings showing high vulnerability (among them a church and an industrial building).

\subsection{Location of the faults}

A difficult question to answer concerns the location of the responsible fault(s). Seismic instrumentation was sparse in Switzerland at that time (four analogue seismic stations located in Zurich, Basel, Neuchatel, and Chur) so locations could not be assessed adequately. So far attempts to locate the events rely on macroseismic data and thus are imprecise. For more than 30 years now, instrumentation has been improved. However, seismic activity was too minimal to detect the active fault that might have triggered the 1964 series. A few small events recorded over the last 30 years support the model of a complex conjugated fault system with quickly changing stress fields in space (Deichmann et al. 2000). Such a model would not contradict geological findings that describe the region as a complex zone of overlaying and partly interlocked nappes disrupted by many tectonic 


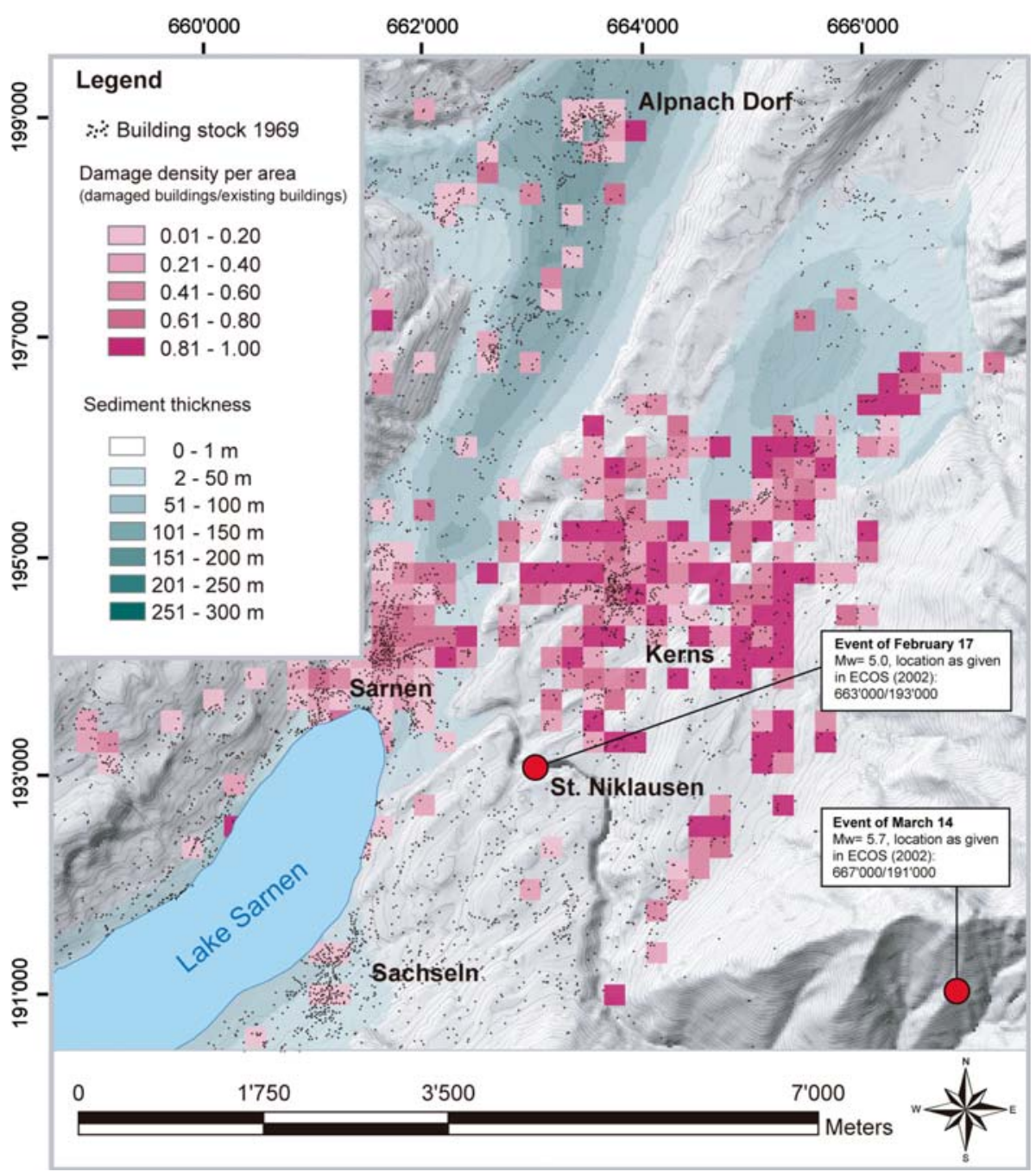

Fig. 9 Percentage of damaged buildings per grid unit for the villages showing the highest intensity. Dark colored squares indicate areas with high portions of damaged buildings. Damage grades are not incorporated

faults, nor would it contradict our interpretation of the 1964 series as a swarm. The earthquakes occurred at shallow depth and we might expect to find surface expression of the faults. Two faults that are mentioned frequently as part of this system west (1) and north of Sarnen (2) are shown in Fig. 8 (Beer 1997; Schindler et al. 1996). Gisler et al. (2004) proposed the left lateral strike-slip fault complex west of Sarnen (1) as the trigger for the 1964 event (Schindler 1980; Schindler et al. 1996). Such a fault mechanism would agree with the area's actual stress field derived from instrumental data (Kastrup et al. 2004). The results of our investigation show that the visible faults are probably not responsible for the two big 1964 events, at least not the part close to the surface. An earthquake with the epicenter located on this fault close to the surface would have produced a damage field different from our reconstruction (Fig. 8). Particularly, the region in 


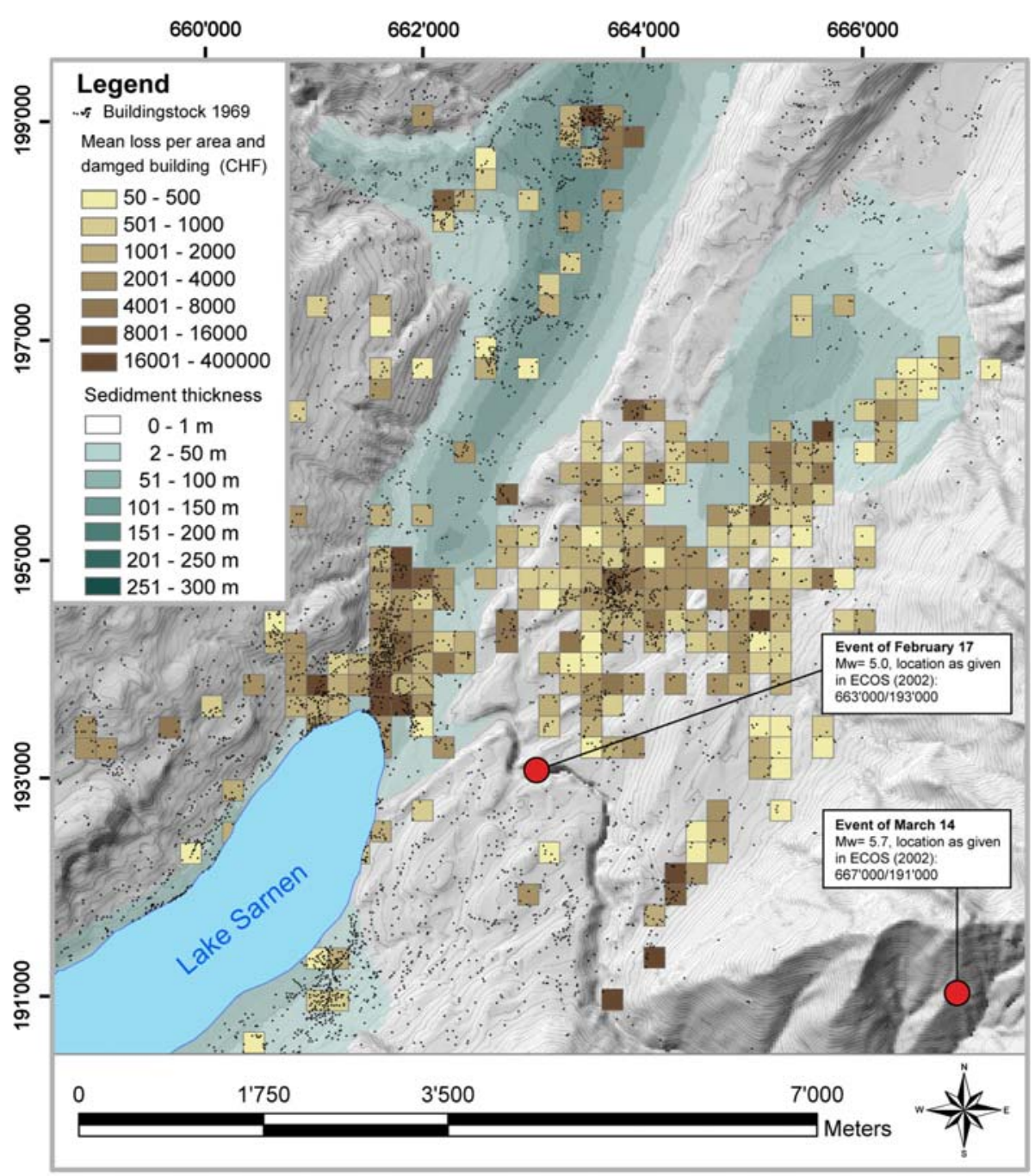

Fig. 10 Average loss per building and grid unit in CHF (1964) for the villages showing the highest intensity. Squares of dark color indicate areas with high repair costs

the immediate vicinity and to the west of this fault shows very low intensities. Our results, in contrast, show that at least the two main shocks occurred closer to the villages of Sarnen and Kerns. However, the location of the source(s) remains an open question and makes it impossible to consider its influence on the damage field. Directivity effects, in particular, might have played an important role. Nevertheless, the data at hand does not allow quantifying the influence of this effect. As mentioned, the damage assessment does not separate the loss of the two damaging shocks. Considering also the lack of instrumental data from close seismic stations makes it impossible to reconstruct the two individual damage fields, as well as to locate the epicenters more precisely than proposed by ECOS (2002). Currently, there is not much hope that further historical documents exist that include information that would solve this problem. 


\section{Site effects: an important factor?}

\subsection{Local ground conditions}

With respect to site effects and damage distribution, the characteristics and thickness of the geotechnically relevant surface layers are important. Below we review the known geological and geotechnical conditions and describe the method we used to clarify them (Fig. 11). Tectonically, the region of interest is north of the autochthonous basement (Aar Massif) of the Alps in the Helvetic nappes that are succeeded in the north by the Swiss Molasse Basin. The geomorphology is characterized by the main valley of the Kanton Obwalden running north-northeast down to Alpnach where it meets Lake Lucerne. This valley is strongly affected by glacial activity from the last ice age. Due to differences in rock hardness, the glacier formed several deep basins and swells that explain the cascaded pattern of the modern valley (Schindler 1980). Parts of Sarnen, for example, are built on one of these, which explains the varying deposit thickness in the area (Fig. 10). The basins are filled with young fluviatile and lacustrine sediments only a little consolidated with a thickness of up to $300 \mathrm{~m}$ (Beer 1997). The groundwater table is high in these sediments (ibid.). Although on some locations north of Sarnen and Alpnach less than $5 \mathrm{~m}$ below the surface, ground failure or liquefaction was not observed during the 1964 earthquake series.

Where side valleys enter the main valley, the sediments are topped by extensive alluvial cones. In contrast to the valley bottom, the quaternary deposits on the mountainside are of minor thickness, consisting mostly of rock fall or slope rubble. Exceptions are the debris fans and the alluvial plain near Kerns, where the deposits reach a thickness of up to $150 \mathrm{~m}$. These are unconsolidated like the fill of the main valley. Where the quaternary deposits are almost absent, the massive layers of the tertiary and cretaceous partially outcrop. On the eastern slope of the main valley, the latter consist mainly of limestone and sandstone as well as marl (Kantonales Oberforstamt 1980). Some minor secondary phenomena (slope instabilities and rock fall) were observed in this part during the two main events. The western slope is dominated by outcrops of flysch and near Sarnen and Alpnach by limestone and sandstone.

The damage field of the 1964 earthquakes cover all these different surface layers. Our experience from comparable sites and earthquakes suggests that these fields will express such alternating ground conditions. Of particular interest are sites on voluminous deposit layers showing low S-wave velocities and strong impedance contrasts, since these sites tend to amplify ground motion on a frequency band that is often similar to the eigenfrequency of buildings. This similarity may lead to resonance effects and more serious damage.

\subsection{Ground investigations: results}

Comparing the damage distribution with sediment thickness (Figs. 8-10) shows that correlation is only partly given. We thus investigated the ground conditions with a statistical analysis of the losses per geological entity and with field experiments concerning the fundamental frequency of resonance.

Our results are given in Fig. 11. In order to check the consistency of these findings, our computational results are given in two different scales: a scale representing the bigger part of the damage field and one showing the inner part of the damage field (approximately restricted to the villages of Sarnen and Kerns, represented by the dashed square). Each pie chart describes the damage spectrum on a specific geological unit as the sum of damage grades (0-4). Dashed bordered charts belong to the inner damage field. While the numbers 


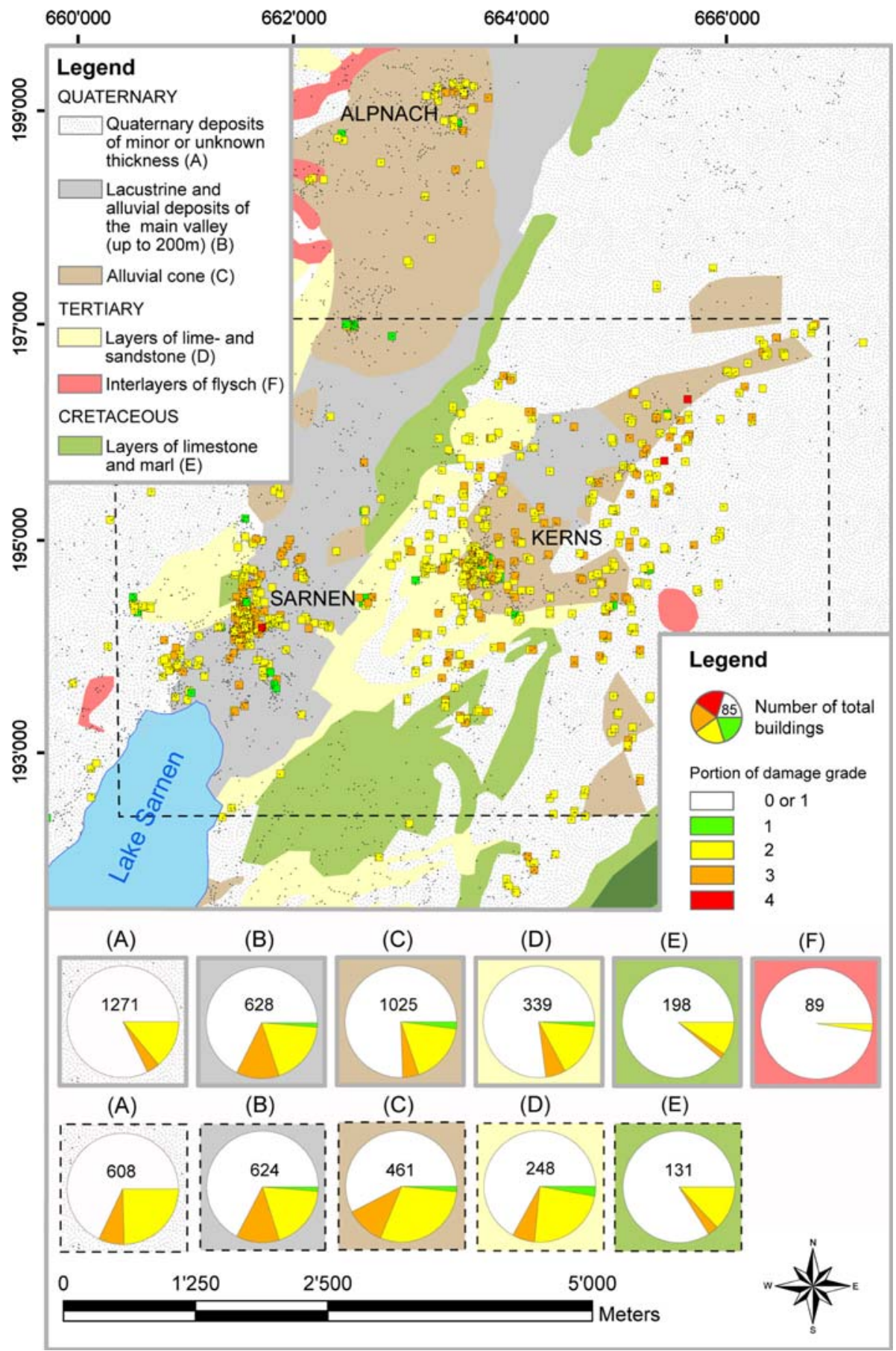

Fig. 11 Damage grades and geology. The charts show the distribution of damage grades per geological unit on two scales. Dashed charts refer to the area defined by the dashed rectangle. The numbers inside the charts represent the existing building stock. This illustration is based on a geological map published in 1980 (Kantonales Oberforstamt) 


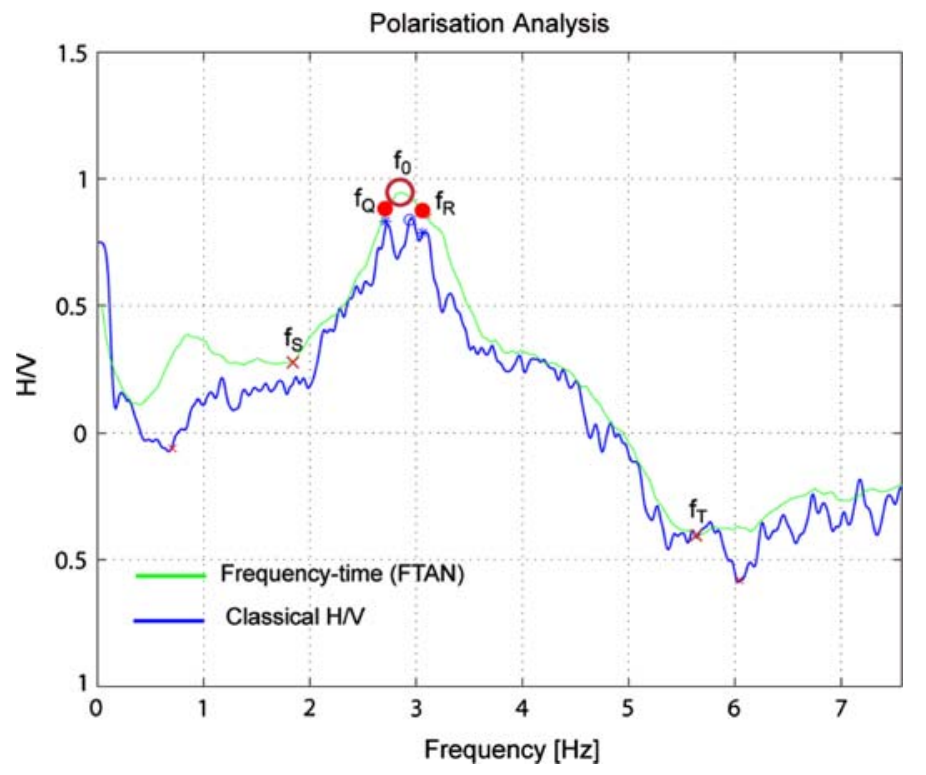

Fig. 12 Example of a chosen $\mathrm{H} / \mathrm{V}$ spectrum

inside the charts summarize the numbers of buildings existing in 1964, the colored segments give information on the proportion of the assessed damage grades. Since grade 1 damage is not completely assessed (see paragraph 2.3), we must note that the segments representing undamaged buildings (white color) include a significant number of grade 1 cases. In general, the ground conditions in Fig. 11 can be divided into two main classes showing similar behaviors during an earthquake: the class of the different types of quaternary deposits on the one side $(\mathrm{A}-\mathrm{C})$ and the rocklike layers of tertiary and cretaceous on the other (D and E). The flysch interlayers (F) are minor since few buildings are located there.

Figure 13 shows the results of our field experiments concerning the fundamental frequency of resonance. It can be measured with ambient vibration $\mathrm{H} / \mathrm{V}$ spectral ratios. In total, we recorded ambient vibration on 75 sites for $20 \mathrm{~min}$ each and computed the data with an algorithm developed by Fäh et al. (2001). The fundamental frequency of resonance indicates the frequency band at which amplification can be strong. Fundamental frequencies of resonance depend primarily on deposit thickness and composition (S-wave velocity). In addition, for all maxima identified in the $\mathrm{H} / \mathrm{V}$ spectral ratio, we computed the quality of the peak. It is defined as the average value of two quality measures in the frequency-time-domain (FTAN, see also Fig. 12):

$$
Q=\frac{\left(Q_{1}+Q_{2}\right)}{2}
$$

$f_{o}$ : $\quad$ Frequency of the H/V-peak: Fundamental frequency of resonance

$\left[f_{Q}, f_{R}\right]: \quad$ Uncertainty range of the fundamental frequency of resonance

$f_{S}: \quad$ Frequency of the first minimum to the left of the H/V-peak

$f_{T}$ : $\quad$ Frequency of the first minimum to the right of the H/V-peak 


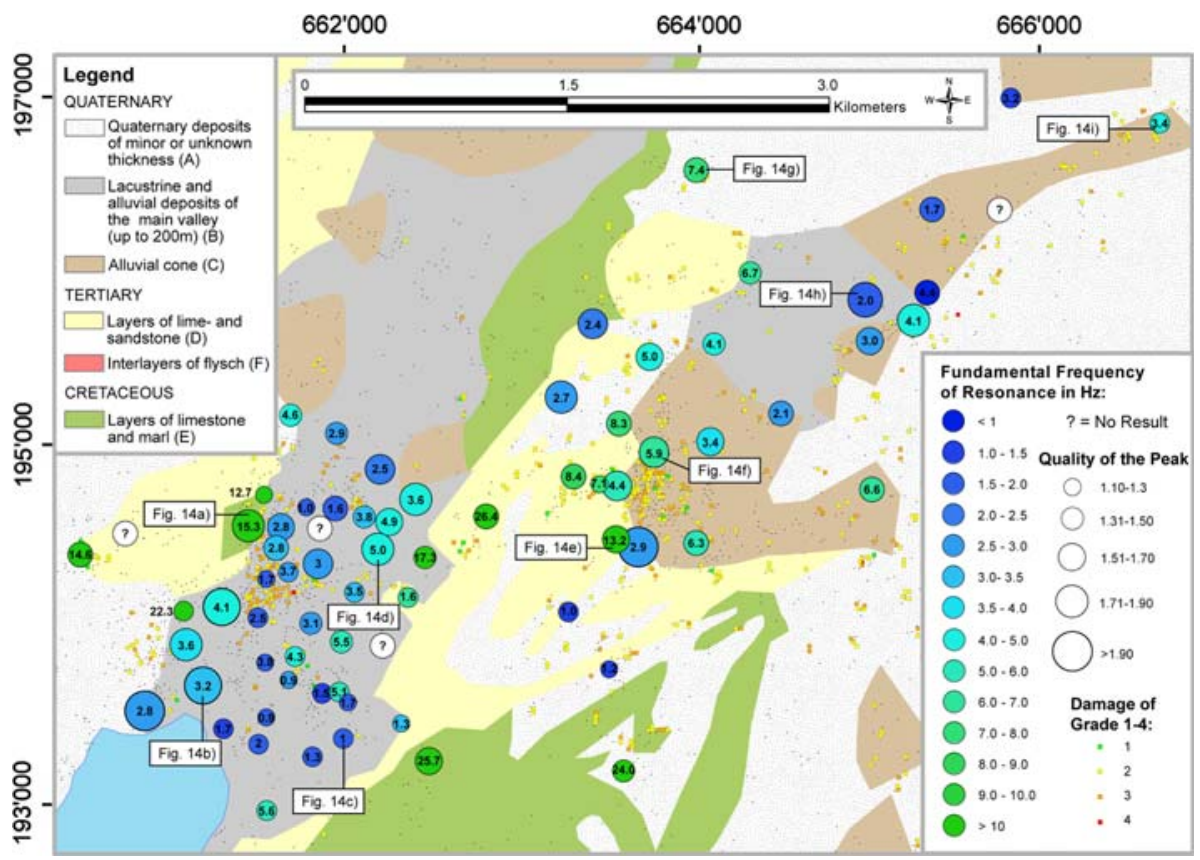

Fig. 13 Geology and fundamental frequency of resonance. Location and results of 64 field experiments on the background of a geological map

First quality measure of the peak $\left(Q_{1}\right)$ :

$$
Q=\frac{\int_{f_{Q}}^{f_{R}} \log 10\left(\frac{H}{V}\right) d f}{\left(f_{R}-f_{Q}\right)}-\frac{\log 10\left(\frac{H}{V}\left(f_{S}\right)\right)+\log 10\left(\frac{H}{V}\left(f_{T}\right)\right)}{2}
$$

Second quality measure of the peak $\left(Q_{2}\right)$ :

$$
Q_{2}=1+\frac{\int_{f_{s}}^{f_{T}} 10^{\left|\log 10\left(\frac{H}{V}\right)-\bar{A}\right|} d f}{\left(f_{T}-f_{S}\right)} \quad \bar{A}=\frac{\int_{f_{s}}^{f_{T}} \log 10\left(\frac{H}{V}\right) d f}{\left(f_{T}-f_{S}\right)}
$$

This peak value is not a quantitative measure of the expected amplification, but qualitatively describes the impedance contrast between sediments and bedrock.

\subsection{Ground investigation: discussion}

Starting with the results from the statistical analysis, we note that damage is more frequent and larger on quaternary deposits. This is clear for the whole damage field as well as the inner part of the affected region (Fig. 11, dashed square), but more obvious in the latter. Particularly, ground types $\mathrm{B}$ and $\mathrm{C}$ show significantly higher rates of damaged objects, given their high portion of damage grade 3 . Ground types $\mathrm{B}$ and $\mathrm{C}$ mainly correspond with the basin of the main valley. Thus, 2D and 3D effects cannot be excluded as long as investigation into this matter has not been done. In contrast, a high value of damage grade 3 is missing for the third ground type of the quaternary class (A). This is due to the thickness characteristics of the sediment layer. Ground types B 
and $\mathrm{C}$ show remarkable thickness for the most part, but type $\mathrm{A}$ is probably thin for wide areas. Consequently, these particular areas are not affected by site amplification in a relevant frequency band. Proceeding to the rocklike ground class, we conclude that the results are ambiguous. While ground types $\mathrm{E}$ and $\mathrm{F}$ fit our expectations by showing lower intensity, damage in type D is significantly higher than anticipated with cumulative damage on a level similar to the quaternary ground classes. However, one difference is visible. Compared to ground types B and C, damage of grade 3 is less pronounced, indicating a lower intensity similar to type A. Nevertheless, the values resulting for ground type D are clearly higher than expected. Why? Figure 11 implies that for ground type D (as well as E and F) the rock may reach the surface area-wide. Of course this is not the case for large parts of this region. It is covered with quaternary deposits of unknown thickness in some places. As with ground type A, we don't know exactly how thick they are. Moreover, the behavior of the rock strongly depends on its state of weathering: a heavily weathered rock behaves more like a sediment layer than a rock in geophysical terms. Our field experiments concerning the fundamental frequency of resonance illustrate that parts of ground type D show clear peaks of moderate quality on the H/V spectrum, unlike rock in a geophysical sense (Figs. 13, 14, west of Kerns). Thus, whether or not weathered rock or quaternary deposits explain this phenomenon, we have strong indications for a surface layer that behaves like a deposit. Apart from this, the results of the field experiments (Fig. 13) clearly correlate deposit thickness and the fundamental frequency of resonance. An empirical formula equates $f_{0}$ with $V_{s} / 4 h$, where $\mathrm{h}$ is the thickness of the relevant surface layer. Although we did not perform a geophysical study of the shear wave velocity for the Sarnen-region, our experience for comparable sites in Switzerland shows that Vs is probably in the range of 400-600 m/s (Havenith and Fäh 2006; Roten and Fäh 2007). Assuming this range for Vs, the formula results in thickness values similar to the data proposed by Beer (1997) and shown in Fig. 10. Most notable are the results for the main valley near Sarnen, where the values fit the shape of the bedrock, with low $\mathrm{f}_{0}$-values along the central valley axis and an increase toward both sides. To the east lies the limestone zone showing results that indicate a more complicated ground situation than our geological data imply. In contrast, the values measured from there on to the northeast are explainable by the thickness and nature of the deposits (Figs. 13, 14).

In general, the qualities of the peaks show wide variety. Nevertheless, a certain pattern is visible. While the peaks in the Kerns region show moderate quality for most of the measured sites, the main valley can be divided into different zones of poor/intermediate/ good quality. Although the measured sites southeast of Sarnen show poor quality, the peak quality is much better on the western border of the plane. To the north of the city center, a zone of peaks with intermediate quality is found. When we compare these patterns with the damage distribution, since peak quality is a measure for impedance contrast, we hardly find correlation. An exception is the zone southwest of Sarnen showing rather low damage (Fig. 9).

Are these observed $\mathrm{f}_{0}$-values of relevance for the building stock of the region? The eigenfrequency of a building is controlled by many parameters. Types of construction and materials like the ground plan and many other factors have an influence. Hence, an adequate eigenfrequency assessment is individual, complex, and impractical for this case. Using general empirical observations, for buildings with 2-4 floors (the majority of the buildings' stock) eigenfrequencies of 3-8 Hz can be expected. Comparing this assumption with the expected soil amplification as a function of frequency band shows correlation for many areas. 

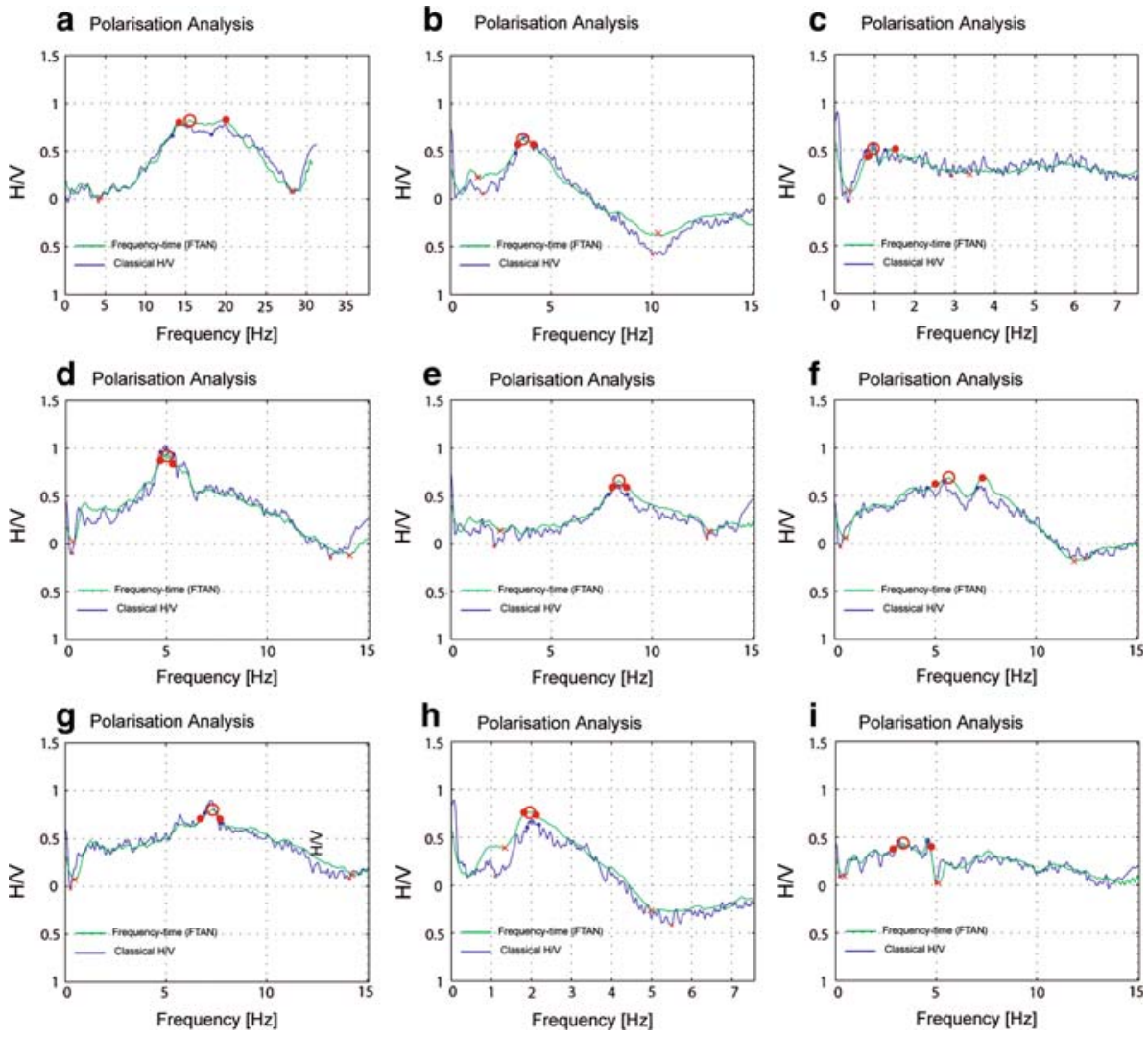

Fig. $14 \mathrm{H} / \mathrm{V}$ spectra of the marked sites in Fig. 13

\section{Conclusion}

Our aim was to analyze the earthquake swarm of 1964 in the Sarnen region. We explored questions related to the location of the source, the characteristics of the damage field, and whether site-effects influenced this damage field.

Given the good documentation of the loss, we assessed the damage with high accuracy. For $95 \%$ of the affected buildings, location and grade of damage were reconstructed. One main characteristic of the damage field is its relatively small extension compared to the observed intensity: a few dozen square kilometers. Our finding agrees with observations that suggest shallow epicenters for this part of central Switzerland. The damage concentrates for the bigger part in the two villages of Sarnen and Kerns, which experienced for both main events an intensity of grade VII. Due to the fact that the historic documents describing the loss give no reference to one of the two damaging shocks, it was not possible to distinguish the damage from each shock.

Two faults with a surface expression discussed here as a possible source of the 1964 events are probably not responsible for them, at least not the part close to the surface. Their position at the periphery of the damage field makes it unlikely that an earthquake on one of these faults would have caused the observed damage. However, these faults are only the visible part of a complex sub-surface fault system. 
In total, about 850 buildings were affected, ranging from damage grade 1 up to a few cases of grade 4 . About $90 \%$ of the damaged objects were either residential buildings or barns. These buildings were responsible for approximate $35 \%$ of the total repair costs. On the other hand, loss to sacral buildings, representing merely $2 \%$ of the damaged buildings, amounted to almost $50 \%$ of the total repair expense. Analyzing the damage field has shown that varying building vulnerability as well as different ground conditions shaped spatial distribution and degree of damage. However, adequate quantification of these influences is difficult. The building vulnerability could only be assessed generally and the unknown source location made it difficult to separate source from site effects. Particularly, the fact that the historical documentation did not allow to split the loss regarding the two strongest shocks turned out to be a strongly limiting factor.

Despite these restrictions, the influence of ground conditions is obvious. Regions of thick sediments in the main valley and the northeast of Kerns show significantly higher damage than places where the rock is covered by thin deposits. An exception is the area dominated by layers of limestone and sandstone between Sarnen and Kerns, where the geological conditions are more complex than expected. A thick layer of weathered bedrock or layers of quaternary sediments in some areas could explain this exception. In general, these findings are supported by the results of field experiments. In most areas where loss occurred, the measured fundamental frequencies of resonance of the soil are in a similar range to the eigenfrequencies of the buildings. In particular, this applies for sites showing a high degree of damage. Furthermore, the gathered $\mathrm{f}_{0}$-values generally confirm known information concerning deposit thickness. More experiments on locations in the limestone and sandstone layers would probably help clarify the geological situation of this zone. More study would also be desirable for locations further away from the inner damage field. Particularly, Engelberg and the lower part of Lucerne would be interesting for further research, since both sustained slight damage at a considerable distance from the epicentral region.

Acknowledgments This paper was prepared while working for a $\mathrm{PhD}$ project at the Swiss Federal Institute of Technology in Zurich. Many people have contributed to its success. We would like to thank all of them. Special thanks go to Vreni Fanger who helped locate buildings and to Christoph Beer who did much previous work with respect to microzonation in our region. We also thank our English editor Dr. Kathleen J. Jackson. Finally, we gratefully acknowledge the financial support of the Swiss National Science Foundation (project number: 205121-100510).

\section{References}

\section{Historical sources}

Allgemeine Volkszeitung (1964) Die Bevölkerung in Obwalden lebt in Furcht. Zofingen. March 21. Newspaper article

Die Woche (1964) In Obwalden geht das Gespenst von Skoplje um. Olten. March 18. Journal article

Kanton Obwalden (1964a) List of damaged churches. StAOW, V-D.03.0735

Kanton Obwalden (1964b) Schadenserhebung zu den Erdbeben von 1964 in der Region Sarnen. StOW, V-D.03.0735

Neue Zürcher Zeitung (1964) Das Erdbeben in Obwalden. Zurich. March 16. Newspaper article

Ostschweizerisches Tagblatt (1964) In Obwalden bebte die Erde. St. Gallen. March 16. Newspaper article

Stuttgarter-Zeitung (1964) Mehrere hundert Nachbeben im Gebiet von Sarnen. Stuttgart. April 7. Newspaper article

Tribune de Lausanne (1964) L'angoisse grandit à Sarnen. Lausanne. March 15. Newspaper article

Von Ah H (1964) Referat anlässlich des Rapportes der Leiter der Kantonalen Zivischutzstellen, vom 20-23. April 1964 in Bern. Unpublished manuscript. StAOW, V-D.03.0735

Vaterland (1964a) Samstag 03.39: die Erde bebt. March 16. Newspaper article

Vaterland (1964b) February 18. Newspaper article 


\section{Scientific literature}

Beer Ch (1997) Erdbebengefährdung in Abhängigkeit vom Geologischen Untergrund. Schweizerische Geotechnische Kommission. Beiträge zur Geologie der Schweiz. Geotechnische Serie 92

Bernardi F, Braunmiller J, Giardini D (2005) Seismic moment from regional surface-wave amplitudes: applications to digital and analog seismograms. BSSA 95(2):408-418

BRGM, EDF and IRSN (2005) SisFrance. http://www.sisfrance.net. Cited 22 Jan 2007

Deichmann N, Ballrin Dolfin D, Kastrup U (2000) Seismizität der Nord- und Zenralschweiz. NAGRA Technischer Bericht 00-05, Wettingen

Eidg. Landestopographie (1971a) Alpnach (Nr. 1170), Landeskarte der Schweiz,1:25,000, Gesamtnachführung 1969. Wabern

Eidg. Landestopographie (1971b) Melchtal (Nr. 1190), Landeskarte der Schweiz,1:25,000, Gesamtnachführung 1969. Wabern

Fäh D, Kind F, Giardini D (2001) A theoretical investigation of average H/V ratios. Geophys J Int 145: 535-549

Fäh D, Giardini D et al (2003) Earthquake Cataloque of Switzerland (ECOS) and the related macroseismic database. Eclogae Geol Helv 96:219-236

Gisler M, Fäh D, Kästli Ph (2004) Historical seismicity in Central Switzerland. Eclogae Geol Helv Swiss J Geosci 97:221-236

Grünthal G (1998) European Macroseimic Scale 1998. Cahiers du Centre Eropéen de Geodynamics et de Séismologie 15. Conseil de l'Europe, Luxembourg

Hainzl S, Kraft T, Wassermann J, Igel H, Schmedes E (2006) Evidence for rainfall-triggered earthquake activity. Geophys Res Lett 33:L19303

Havenith HB, Fäh D (2006) S-wave velocity measurements applied to the seismic microzonation of Basel, Upper Rhine Graben. Geophys J Int 170:346-358

Husen S, Bachmann C, Giardini D (2007) Locally triggered seismicity in the central Swiss Alps following the large rainfall event of August 2005. Geophys J Int 171:1126-1134

Kantonales Oberforstamt (1980) Geologische Karte des Kantons Obwalden. Sarnen

Kastrup U, Zoback M, Deichmann N, Evans K, Giardini D, Michael A (2004) Stress field variations in the Swiss Alps and the northern Alpine foreland derived from inversion of fault plane solutions. J Geophys Res 109:B01402

Ritzmann-Blickenstorfer H (1996) Historische Statistik der Schweiz/unter der Leitung von Hansjörg Siegenthaler. Chronos, Zürich

Roten D, Fäh D (2007) A combined inversion of Rayleigh wave dispersion and 2-D resonance frequencies. Geophys J Int 168(3):1261-1275

Schindler C (1980) Geologisch-geotechnische Voruntersuchungen der N8 zwischen Sarnen und dem Brünig, Strasse und Verkehr, Nr. 5

Schindler C, Beer C, Mayer-Rosa D, Rüttener E, Wagner J-J, Jaquet J-M, Frischknecht C (1996) Integrierte Auswertung von seismischen und bodenspezifischen Parametern: Gefährdungskarten im Kanton Obwalden. Bundesamt für Umwelt, Wald und Landschaft. Landeshydrologie und -geologie. Geologische Berichte. Nr. 19

Schwarz-Zanetti G, Fäh D, Schibler R, Masciadri V, Kästli P, Giardini D (2003) The earthquake in Unterwalden and the rockslide from the Bürgenstock into Lake Lucerne on September 18, 1601. Eclogae Geol Helv Swiss J Geosci 96:219-236

Schwarz-Zanetti G, Deichmann N, Fäh D, Masciadri V, Kästli P, Schnellmann M, Jimenez M (2006) Das Unterwaldner Erdbeben vom 18. September Naturkatastrophen in der Zentralschweiz. Der Geschichtsfreund 159:11-28

Swiss Federal Statistical Office (2006) Consumer price index: http://www.bfs.admin.ch. Cited 15 Feb 2007

Swiss Seismological Service (2002) ECOS-Earthquake Catalogue of Switzerland. http://www.seismo. ethz.ch. Cited 8 Nov 2006 